\title{
DERMANYSSUS GALLINAE - OVERVIEW: LIFE CYCLE, MORPHOLOGY, PREVALENCE AND CONTROL MEASURES IN POULTRY FARMS
}

\author{
Slobodan Knežević1 ${ }^{*}$, Marko Pajić1 , Aleksandra Petrović , Suzana Vidaković1, \\ Jelena Babić ${ }^{1}$, Milica Živkov-Baloš1 ${ }^{1}$ Ivan Pušić1 ${ }^{1}$, Sara Savić1 , Igor Stojanov ${ }^{1}$ \\ ${ }^{1}$ Scientific Veterinary Institute „Novi Sad“, Novi Sad, Serbia \\ ${ }^{2}$ University of Novi Sad, Faculty of Agriculture, Department of \\ Environmental and Plant Protection, Novi Sad, Serbia
}

Abstract

Dermanyssus gallinae or the poultry red mite is currently the most important ectoparasite affecting egg-laying hens in several countries causing reduced poultry welfare, mortality and even allergic reactions in poultry farms workers. Its short life cycle, which in optimal conditions can be completed within 7 days, and ability to survive in extreme circumstances without a blood meal up to 13 months, and the ability to infest new flock, makes it even more difficult to eradicate. Dermanyssus gallinae prevalence rates in different European countries, including Serbia, can reach up to $80-90 \%$. Also, the poultry red mite is responsible in vector transmission of several bacterial and viral avian diseases, including Salmonella spp, Chlamydia spp., Escherichia coli, Staphylococcus spp., Pasteurella multocida, Newcastle disease and Fowl poxvirus. Besides that, the poultry red mite can also transfer antimicrobial resistance genes by carrying pathogenic bacterial flora. Control of Dermanyssus gallinae can be divided into conventional and alternative methods. Conventional methods are mostly focused on preventing infestations and/or killing Dermanyssus gallinae, while alternative methods include the use of essential oils, vaccines, light, odors, predatory mites, fungi, nematodes and bacterial endosymbionts, and temperature in order to eliminate the poultry red mite. Nevertheless, this small ectoparasite still makes millions worth damage to global poultry industry.

Key words: Poultry red mite, egg-laying hens, prevalence, vector transmission, prevention

\footnotetext{
${ }^{1 *}$ Corresponding author: slobodan.knezevic@niv.ns.ac.rs
} 


\title{
DERMANYSSUS GALLINAE - PRIKAZ: RAZVOJNI CIKLUS, MORFOLOGIJA, PREVALENCIJA I MERE KONTROLE NA ŽIVINARSKIM FARMAMA
}

\author{
Slobodan Kneževićc ${ }^{*}$, Marko Pajić1 ${ }^{1}$, Aleksandra Petrović ${ }^{2}$, Suzana Vidaković1, \\ Jelena Babić ${ }^{1}$, Milica Živkov-Baloš1 , Ivan Pušić1 ${ }^{1}$ Sara Savić1 Igor Stojanov $^{1}$ \\ ${ }^{1}$ Naučni institut za veterinarstvo „Novi Sad“, Novi Sad, Srbija \\ ${ }^{2}$ Univerzitet Novi Sad, Poljoprivredni fakultet, Departman \\ za fitomedicinu i zaštitu bilja, Novi Sad, Srbija
}

\section{Kratak sadržaj}

Dermanyssus gallinae ili crvena kokošija grinja je trenutno jedan od najbitnijih ektopatazita koji pogađa koke nosilje, dovodeći u nekoliko zemalja do narušavanja dobrobiti, mortaliteta, pa čak i do pojave alergijske reakcije kod farmera. Razvojni ciklus ovog parazita koji uz optimalne uslove može biti kompletiran unutar 7 dana, sposobnost preživljavanja u ekstremnim uslovima bez krvnog obroka do 13 meseci i mogućnost da inficira novo jato predstavlja veoma težak način za eradikaciju. Prevalencija Dermanyssus gallinae u mnogim evropskim zemljama, uključujući i Srbiju, može da dostigne čak 80 do 90 \%. Takođe, crvena kokošija grinja je kao vektor odgovorna za prenos uzročnika raznih bakterijskih i virusnih bolesti, uključujući Salmonella spp., Chlamydia spp., Escherichia coli, Staphylococcus spp., Pasteurella multocida, virusa Newcastle bolesti i Fowl poxvirusa. Pored toga, crvena kokošija grinja ima mogućnost, prenošenjem patogenih bakterija, da prenese i gene antimikrobne rezistencije. Mere kontrole Dermanyssus gallinae se mogu podeliti na dve metode: konvencionalnu i alternativnu. Konvencionalna metoda je većinom fokusirana na prevenciji infestacije i/ ili ubijanju parazita Dermanyssus gallinae, dok alternativna metoda podrazumeva upotrebu esencijalnih ulja, vakcina, svetla, mirisa, predatora, gljivica, nematodnih i bakterijskih endosimbioza, kao i temperature u cilju iskorenjivanja crvene kokošije grinje. Naime, ovaj ektoparazit i dalje dovodi do milionskih šteta u živinarskoj proizvodnji širom sveta.

Ključne reči: Crvena kokošija grinja, koke nosilje, prevalencija, vektorski prenosive bolesti, prevencija 


\section{INTRODUCTION}

Dermanyssus gallinae (Acari, Mesostigmata, Dermanyssoidea, Dermanyssidae) or the poultry red mite is an obligatory blood-sucking parasite of both domestic and wild birds. The poultry red mite is a cosmopolitan parasite and has been confirmed on 30 avian and 20 mammal species (Nordenfors, 2000). This ectoparasite poses a significant threat to egg-laying hens in many parts of the world, including Europe (George et al., 2015). The cost of Dermanyssus gallinae is difficult to evaluate on a global level, but poultry farmers estimated the costs for preventive and control measures, as well as higher feed intake, higher mortality and lower egg quality due to the damage caused by poultry red mite to be millions of Euros/dollars in production and animal losses, treatments, veterinary bills, and lost working days (Van Emous et al., 2006).

\section{MORPHOLOGY AND LIFE CYCLE}

Dermanyssus gallinae is a small ectoparasitic mite approximately $1.5 \mathrm{~mm}$ in length, which varies in color from gray to brown/red depending on feeding status. The poultry red mite does not have eyes, but locates its hosts using a combination of several stimuli, including vibration, heat and carbon dioxide sensing through hair-like appendages called setae, normally clustered at the palpal or tarsal extremities (Kilpinen, 2005; Pritchard et al., 2015). Once on a host, the nymphs and females feed for short periods usually during darkness, while males do so very occasionally. Dermanyssus gallinae stays on the birds for only $0.5 \pm 1.5 \mathrm{~h}$ to feed, while the rest of time they are hidden under the conveyor belts of eggs and cage supports, under the rods, in nest boxes, beneath troughs and in small cracks and crevices in the poultry house walls.

Complete development of Dermanyssus gallinae, from egg, through one larval stage and two nymphal stages, to adult usually takes about one to two weeks depending on environmental factors. A six-legged white larva hatches from the egg under warm conditions at the temperature of $28 \pm 30^{\circ} \mathrm{C}$ within $2 \pm 3$ days. After one day, the larva molts, without feeding, to a protonymph, which has 8 legs. After feeding, the protonymph transforms to a deutonymph, which feeds again and transforms to female or male adult. The temperatures in laying hen facilities generally maintained between 18 and $21^{\circ} \mathrm{C}$ provide optimal conditions for the development of Dermanyssus gallinae. Under such conditions, the lifecycle of poultry red mite can be completed within 7 to 17 days (Maurer and Baumgärtner, 1992). Soon after molting, the adults mate. Within $12 \mathrm{~h}$, females feed and deposit eggs several times. In a lifetime, female Derman- 
yssus gallinae is able to lay about 30 eggs. The egg is oval shaped $(400 \times 270 \mu)$, smooth and white (Chauve, 1998). In exploitation, which usually exceeds one full year, Dermanyssus gallinae may be present all the time, but highest density occurs during hot and humid seasons (Nordenfors and Hoglund, 2000). The reproductive potential enables Dermanyssus gallinae to triple its number in only 10 days. This includes all development stages (Pavlović et al., 2017). According to several authors the poultry red mite can persist in extreme conditions for up to 8, 9 or even 13 months without a meal (Chauve, 1998; Nordenfors, 2000; Pavlićević et al., 2007). Even when laying hens are removed from premises between production cycles the poultry red mite may survive long enough to infest new flock because of their ability to starve longer than the regular pause between production cycles. Only an extraordinary pause of 2 years should be long enough for the present poultry red mite to die out. Only in this circumstance, and with no alternative food sources, the required period for PRM to die out can be prolonged (Pavlićević et al., 2007).

\section{PREVALENCE OF DERMANYSSUS GALLINAE IN EUROPEAN COUNTRIES}

Some studies revealed higher prevalence rates in less intensive farming systems, including organic, free range farming and barns, which are due to the ability of Dermanyssus gallinae to hide in cracks and fissures and avoid control methods.

Variation in prevalence throughout Europe is shown in Table 1. In different European countries Dermanyssus gallinae prevalence rates can reach up to $80-90 \%$ as shown for the United Kingdom, France, The Netherlands, Serbia, Montenegro (Sparagano et al., 2009). Investigations that were carried out in laying hen farms, duckling and gosling broiler farms in Poland showed even higher prevalence (100\%) (Cencek, 2003). 
Table 1. Prevalence (\%) of Dermanyssus gallinae in egg-laying hen systems (Sparagano et al., 2009)

\begin{tabular}{|l|c|c|c|c|c|}
\hline \multirow{2}{*}{ Country } & \multicolumn{5}{|c|}{ Prevalence (\%) by production system } \\
\cline { 2 - 6 } & Cage & Barn & Free-range & Backyard & Organic \\
\hline United Kingdom & $8-88$ & 33 & 60 & - & - \\
\hline Denmark & 32 & 50 & 68 & - & 36 \\
\hline France & 72 & 50 & 56 & - & 80 \\
\hline The Netherlands & 82 & 83 & - & - & 78 \\
\hline Italy & 74 & - & - & - & - \\
\hline Montenegro & $30-80$ & - & - & - & - \\
\hline Norway & 23 & - & - & - & - \\
\hline Poland & 100 & 100 & - & - & - \\
\hline Serbia & 90 & - & - & - & - \\
\hline Sweden & 4 & 33 & - & 67 & - \\
\hline
\end{tabular}

“_ data not available

Hence, Höglund et al. (1995) have shown that the prevalence of Dermanyssus gallinae actually depends on the flock housing system, where the infestation rates were $4 \%$ in cage systems, $33 \%$ in alternative systems and $67 \%$ in backyard flocks.

Studies in industrial egg production systems in Portugal have shown the presence of Dermanyssus gallinae in $94 \%$ of the laying hen units sampled (Waap et al., 2017).

Large populations of Dermanyssus gallinae in laying hen facilities may result in decreased egg production, egg quality, increased stress, mortality and morbidity (Mul et al., 2009).

\section{PATHOGENS ASSOCIATED WITH DERMANYSSUS GALLINAE}

Dermanyssus gallinae can act as a vector for bacteria and viruses. It is well established that Dermanyssus gallinae can be implicated in the transmission of vector-borne diseases. However, their role in the natural transmission cycles of pathogenic agents is poorly known; thus, they are mostly ignored as vectors of human or animal diseases. Bacterial and viral avian diseases potentially associated with Dermanyssus gallinae as a vector (according to relevant scientific literature) are reviewed in Table 2. 
Table 2. Bacterial and viral avian diseases which are transmitted by Dermanyssus gallinae (Moro et al., 2009)

\begin{tabular}{|c|c|c|}
\hline & Details & Pathogen \\
\hline \multirow{6}{*}{ Bacteria } & \multirow{4}{*}{ Isolated from mites } & Salmonella Gallinarum \\
\hline & & Chlamydia spp. \\
\hline & & Escherichia coli \\
\hline & & Staphylococcus spp. \\
\hline & \multirow{2}{*}{ Transmission demonstrated } & Salmonella Enteritidis \\
\hline & & Pasteurella multocida \\
\hline \multirow{2}{*}{ Viruses } & Isolated from mites & Newcastle disease \\
\hline & Transmission demonstrated & Fowl poxvirus \\
\hline
\end{tabular}

The use of antimicrobial drugs for prophylactic purposes or therapy can lead to the formation of resistant strains of different bacterial species. These resistant bacterial strains are excreted by animal excrements. In this incidence PRM come in contact with those strains and become vectors who transmit the antimicrobial resistance genes (Stojanov et al., 2017). Some studies have shown that Escherichia coli, Enterobacter sp. Citrobacter sp., and Pseudomonas aeruginosa strains found in Dermanyssus gallinae were resistant to amoxicillin, ampicillin, and colistin (Stojanov et al., 2016).

Moro et al. (2009) demonstrated that, immediately after the experimental infection, Salmonella spp. was found in $29 \%$ of mites infected by a blood meal and in $55 \%$ of mites infected by cuticular contact. Earlier studies showed that Salmonella spp. could survive inside the mites for up to 4 months (Zeman et al., 1982). In humans, Dermanyssus gallinae may cause allergic reactions (Chauve, 1998).

\section{CONTROL STRATEGIES}

Despite many methods, the control of Dermanyssus gallinae is difficult for numerous reasons. First of all, mites spend most of the time in inaccessible cervices and leave their resting place only to eat, which happens for only 30 to 60 minutes every few days. This makes the control difficult to manage, especially if using acaricides that require the contact the target to be effective.

The control of Dermanyssus gallinae can be divided into two parts: conventional methods and alternative methods. The conventional methods mostly focus on killing or preventing infestations by maintaining good hygiene 
practices and regular cleaning of poultry facilities, which can remove large proportions of the poultry red mite populations, as well as their eggs (Nordenfors and Höglund, 2000). Worldwide, Dermanyssus gallinae has typically been controlled using several synthetic acaricides including organochlorines, organophosphates, pyrethrin, pyrethroids, carbamates, amitraz, and endectocides (Chauve, 1998). The use of synthetic acaricides is limited in many European countries by imposing stricter legislation regarding active ingredients. Another problem associated with acaricide use is the possibility of poultry red mite to develop resistance (Sparagano et al., 2014), as well as the risk of exposing eggs, poultry and humans to their residues (Hamscher et al., 2003).

Another useful product in controlling poultry red mite is silica dust. The main benefit of this product is its ability to immobilize poultry red mite by adhering to its body and to cause damage to its cuticle, which leads to severe dehydration and death (Mul et al., 2009).

Many alternative methods have been announced and used in the control of poultry red mite for years, including essential oils, vaccines, light, odors, predatory mites, fungi, nematodes and bacterial endosymbionts (Mul et al., 2009; Sparagano et al., 2014), but none of them have yet given relevant contribution in clinical practice. Development of products based on $\mathrm{SiO} 2$ (Kilpinen and Steenberg, 2009; Schulz, 2014) is the most important, but insufficient in clinical practice of Dermanyssus gallinae control. The use of insecticides still remains dominant (Sparagano et al., 2014; Pritchard et al., 2015).

However, important improvement in Dermanyssus gallinae control has been noticed in 2017. A novel systemic acaricide Exzolt ${ }^{\mathrm{tw}}(10 \mathrm{mg} / \mathrm{mL}$ fluralaner solution, MSD Animal Health) appeared in the market. This product is based on active substance fluralaner and can be administrated per os, making it easy and safe in practical use on farms (Dolz, 2017).

In order to provide a safe, rational and highly efficient Dermanyssus gallinae control mechanical methods have been improved and combined with a range of existing applications and formulations, including new oil-based formulation (Pavlićević et al., 2017).

\section{CONCLUSION}

The fact that Dermanyssus gallinae causes huge problems worldwide manifested as poor egg quality and decreased production, mortality of poultry and transmission of several bacterial and viral diseases emphasizes the need and importance of future investigation and development of novel control methods. The monitoring of Dermanyssus gallinae is an important instrument in 
recognizing the risk and taking appropriate measures on time. Cooperation between veterinarians, scientists and farmers can help to identify effective new control and eradication methods.

\section{ACKNOWLEDGEMENTS}

The research was supported by a Training school at Itea, Greece, provided by COST Action FA1404 "Improving current understanding and research for sustainable control of the poultry red mite Dermanyssus gallinae (COREMI)" and the Ministry of Education Science and Technological Development, Republic of Serbia, Project numbers TR 31084 and TR 31071.

\section{REFERENCES}

1. Hamscher G., Priess B., Hartung J., Nogossek M.I., Gluender G., Nau H.: Determination of propoxur residues in eggs by liquid chromatographydiode array detection after treatment of stocked housing facilities for the poultry red mite (Dermanyssus gallinae). Analytica-Chimica-Acta, 483, 1926, 2003.

2. Cencek T.: Prevalence of Dermanyssus gallinae in poultry farms in Silesia Region in Poland. Bulletin-Veterinary institute in Pulawy, 47, 2, 465-470, 2003.

3. Chauve C.: The poultry red mite Dermanyssu gallinae (De Geer, 1778): current situation and future prospects for control. Veterinary parasitology, 79, 3, 239-245, 1998.

4. Dolz R.: Introduction of Exzolt (Fluralaner $10 \mathrm{mg} / \mathrm{mL}$ solution) - A new product for treatment of poultry red mite infestation in chickens. In: Abstract book, $3^{\text {rd }}$ COST Conference, Improving current understanding and research for sustainable control of the poultry red mite Dermanyssus gallinae (COREMI), 20-21.September, Oeiras, Portugal, 2017.

5. George D.R., Finn R.D., Graham K.M., Mul M.F., Maurer V., Moro C.V., Sparagano O.A.: Should the poultry red mite Dermanyssus gallinae be of wider concern for veterinary and medical science? Parasites and vectors, 8 , $1,178,2015$.

6. Höglund J., Nordenfors H., Uggla A.: Prevalence of the poultry red mite, Dermanyssus gallinae, in different types of production systems for egg layers in Sweden. Poultry Science, 74, 11, 1793-1798, 1995.

7. Kilpinen O., Steenberg T.: Inert dusts and their effect on the poultry red mite (Dermanyssus gallinae). Experimental and Applied Acarology, 48, 5162, 2009. 
8. Kilpinen O.: How to obtain a bloodmeal without being eaten by a host: the case of poultry red mite, Dermanyssus gallinae. Physiological Entomology, 30, 3, 232-240, 2005.

9. Maurer V., Baumgärtner, J.: Temperature influence on life table statistics of the chicken mite Dermanyssus gallinae (Acari: Dermanyssidae). Experimental and Applied Acarology, 15, 1, 27-40, 1992.

10. Moro C.V., De Luna C.J., Tod A., Guy J.H., Sparagano O.A., Zenner L.: The poultry red mite (Dermanyssus gallinae): a potential vector of pathogenic agents. Experimental and Applied Acarology, 48, 1-2, 93-104, 2009.

11. Mul M., van Niekerk T., Chirico J., Maurer V., Kilpinen O., Sparagano O.A., Gjevre A.G.: Control methods for Dermanyssus gallinae in systems for laying hens: results of an international seminar. World's Poultry Science Journal, 65, 4, 589-600, 2009.

12. Nordenfors H., Hoglund J.: Long term dynamics of Dermanyssus gallinae in relation to mite control measures in aviary systems for layers. British poultry science, 41, 5, 533-540, 2000.

13. Nordenfors H.: Epidemiology and Control of the Poultry Red Mite, Dermanyssus gallinae; Doctoral thesis Swedish University of Agricultural Sciences, Uppsala, 2000.

14. Pavlićević A., Pavlović I., Dotlić M.: A contribution to information on starvation survival capacity of poultry red mite Dermanyssus gallinae. Lucrari Stiintifice Medicina Veterinaria, 50, 9, 485-491, 2007.

15. Pavlićević A., Yoon JU., Pavlović I.: Control of red poultry mite (Dermanyssus gallinae) by mechanical effect: the choice of current improvements of formulations, application and concept. $3^{\text {rd }}$ COST Conference, Improving current understanding and research for sustainable control of the poultry red mite Dermanyssus gallinae (COREMI), 20-21.September, Oeiras, Portugal, 2017.

16. Pavlović I., Pavlićević A., Yoon J.U., Dotlić M.: Contribution to the general knowledge of Dermanyssus gallinae reproduction after feeding. In: Abstract book, $3^{\text {rd }}$ COST Conference, Improving current understanding and research for sustainable control of the poultry red mite Dermanyssus gallinae (COREMI), 20-21.September, Oeiras, Portugal, 2017.

17. Pritchard J., Kuster T., Sparagano O.A., Tomley F.: Understanding the biology and control of the poultry red mite Dermanyssus gallinae: a review. Avian Pathology, 44, 3, 143-153, 2015.

18. Schulz J.: Maßnahmen zur Bekämpfung der Roten Vogelmilbe (Dermanyssus gallinae) in der ökologischen Legehennenhaltung. Doctoral dissertation, Freie Universität Berlin, 2014. 
19. Sparagano O.A., George D.R., Harrington D.W.J., Giangaspero A.: Significance and control of the poultry red mite, Dermanyssus gallinae. Annual review of entomology, 59, 447-466, 2014.

20. Sparagano O.A., Pavlićević A., Murano T., Camarda A., Sahibi H., Kilpinen O., Mul M., van Emous R., le Bouquin S., Hoel K., Cafiero M.A.: Prevalence and key figures for the poultry red mite Dermanyssus gallinae infections in poultry farm systems. Experimental and Applied Acarology, $48,1-2,3-10,2009$.

21. Stojanov I., Horvatek Tomić D. H., Pajić M., Pavlović I., Todorović D.: The poultry red mite (Dermanyssus gallinae) as a vector of antimicrobial resistance. In 2nd COST Conference and MC Meeting of COST Action FA 1404 COREMI, January 2016.

22. Stojanov I., Horvatek Tomić D., Pušić I., Pavlović I., Todorović T.: The bacterial flora of Dermanyssus gallinae and its antimicrobial resistance. In: Abstract book, $3^{\text {rd }}$ COST Conference, Improving current understanding and research for sustainable control of the poultry red mite Dermanyssus gallinae (COREMI), 20-21.September, Oeiras, Portugal, 2017.

23. Van Emous R.A., Fiks-Van Niekerk T.G.C.M., Mul M.F.: $€ 11$ million damage for the sector: enquiry into the cost of mites to the poultry industry. De pluimveehouderij, 35, 8-9, 2006.

24. Waap H., Gomes J., Nunes T., Leite P.: A survey on Dermanyssus gallinae in intensive poultry units in Portugal. In: Abstract book, $3^{\text {rd }}$ COST Conference, Improving current understanding and research for sustainable control of the poultry red mite Dermanyssus gallinae (COREMI), 20-21.September, Oeiras, Portugal, 2017.

25. Zeman P., Stika V., Skalka B., Bartik M., Dusbabek F., Lavickova M.: Potential role of Dermanyssus gallinae (De Geer, 1778) in the circulation of the agent of pullurosis-typhus in hens. Folia parasitologica, 29, 4, 371-374, 1982. 